\title{
First record of Anastrepha parishi Stone (Diptera, Tephritidae) and its host in Brazil
}

\author{
Cristiane Ramos de Jesus ${ }^{1}$, Manoela Nobre de Oliveira ${ }^{1}$, Miguel Francisco de Souza Filho ${ }^{2}$, \\ Ricardo Adaime da Silva ${ }^{1} \&$ Roberto Antonio Zucchi ${ }^{3}$
}

\begin{abstract}
'Embrapa Amapá. Rodovia JK, km 5, 68903-000, Macapá -AP. cristiane.bolsista@cpafap.embrapa.br; manoela.87@uol.com.br; adaime@cpafap.embrapa.br.

${ }^{2}$ Instituto Biológico, Caixa Postal 70, 13012-970, Campinas-SP. miguelf@ biologico.sp.gov.br

${ }^{3}$ Departamento de Entomologia, Fitopatologia e Zoologia Agrícola. Escola Superior de Agricultura "Luiz de Queiroz", Universidade de São Paulo.razucchi@esalq.usp.br
\end{abstract}

\begin{abstract}
First record of Anastrepha parishi Stone (Diptera, Tephritidae) and its host in Brazil. Anastrepha parishi Stone, 1942 was reared in fruits of Oenocarpus bacaba Martius, 1823 (Arecaceae) collected in Pracuúba, State of Amapá. This is the first record of an Anastrepha species in a native species of Arecaceae.
\end{abstract}

KEYWORDS. Amazon; Arecaceae; diversity; fruit fly; Oenocarpus bacaba.

RESUMO. Primeiro registro de Anastrepha parishi Stone (Diptera, Tephritidae) e seu hospedeiro no Brasil. Anastrepha parishi Stone, 1942 foi obtida de amostras de frutos de Oenocarpus bacaba Martius, 1823 (Arecaceae), coletadas em Pracuúba, estado do Amapá. Este é também o primeiro registro de uma espécie de Anastrepha obtida de uma espécie nativa de Arecaceae.

PALAVRAS-CHAVE. Amazônia; Arecaceae; diversidade; moscas-das-frutas; Oenocarpus bacaba.

Until 2000, there were records of only three fruit fly species in the State of Amapá (Silva \& Ronchi-Teles 2000) - Anastrepha coronilli Carrejo \& González, 1993, A. striata Schiner, 1868, and Bactrocera carambolae Drew \& Hancock, 1994. However, as fruit fly diversity studies intensified in recent years in that state, another 16 species were recorded, totaling 19 species (18 of Anastrepha), considering the species herein discussed.

Anastrepha parishi was originally described from specimens collected in Guiana, but also occurs in Costa Rica (Gonzáles et al. 1988), Suriname and Venezuela, and was associated in the latter country with guava (first host known) (Caraballo 1981).

During fruit samplings in tephritid bioecology studies, a sample of Oenocarpus bacaba Martius, 1823 (Arecaceae) was collected in the locality of Retiro, municipality of Pracuúba $\left(13^{\circ} 94^{\prime} 03.3^{\prime \prime} \mathrm{N}\right.$ and $\left.50^{\circ} 56^{\prime} 56.6^{\prime \prime} \mathrm{W}\right)$, in the northern part of the State of Amapá, Brazil. From that sample (272 fruits, 690g), collected in December 2006, six puparia were obtained (infestation index: 8.69 puparia/kg fruit and 0.02 puparia/fruit), from which four fruit flies emerged ( 3 females and 1 male). The females were identified as Anastrepha parishi Stone, 1942. Therefore, this is the first record of A. parishi in Brazil and also in fruits of $O$. bacaba as host. Voucher specimens are deposited at Embrapa Amapá collection.
Oenocarpus bacaba is a single-stemmed palm native to the Amazon Region, about 20m in height, popularly known as bacaba. Flowering occurs between June and August, and the fruit ripens after 6 to 8 months. Yield may reach 3 clusters ( 6 to $8 \mathrm{~kg}$ ) per plant/year. The fruit is oleaginous, with a purpleviolaceous color, 1.4 to $2.0 \mathrm{~cm}$ in diameter; the exocarp corresponds to $35 \%$ and the mesocarp to $47 \%$ of the fruit in weight. The fruit pulp is used to prepare a luscious and nutritive beverage, known as "bacaba wine" (Souza et al. 1996; Gomes 2006).

The importance of this record of A. parishi in O. bacaba must be highlighted because, in addition to the fact that it is the second known host of this fruit fly, this is the first record of a palm native to the American Continent as host to an Anastrepha species. Previously, A. suspensa had been associated with date, Phoenix dactylifera L. (Windeguth et al. 1972), an exotic species of Arecaceae in the American Continent.

Acknowledgments. To Agência de Desenvolvimento da Amazônia and Secretaria de Estado da Ciência e Tecnologia do Amapá, for financial support to the research, and Conselho Nacional de Desenvolvimento Científico e Tecnológico for a RSD fellowship granted to the first author. 


\section{REFERENCES}

Caraballo, C. J. 1981. Las moscas de frutas del genero Anastrepha Schiner, 1868 (Diptera, Tephritidae) de Venezuela. Dissertation, Universidad Central de Venezuela, Maracay. xi $+210 p$. Gomes, R. P. 2006. Fruticultura brasileira. São Paulo, Nobel. 446p. Gonzáles, I. M.; H. J. Lezana \& L. F. Jirón. 1988. Anastrepha fruit flies in Costa Rica: three new records. Revista de Biologia Tropical 36: 333-335.
Silva, N. M \& B. Rochi-Teles. 2000. Amapá, Amazonas, Pará, Rondônia e Roraima, p. 203-209. In: Malavasi, A.; Zucchi, R. A. (ed.). Moscas-das-frutas de importância econômica no Brasil: conhecimento básico e aplicado. Ribeirão Preto, Holos, 327 p.

Souza, A. G. C.; N. R. Sousa; S. E. L. Silva; C. D. M. Nunes; A. C. Canto \& L. A. A. Cruz. 1996. Fruteiras da Amazônia. Brasília, EmbrapaSPI; Manaus: Embrapa- CPAA, 204 p.

Windeguth, D. L. Von; W. H. Pierce \& L. F. Steiner. 1972. Infestations of Anastrepha suspensa in fruit on Key West, Florida. Florida Entomologist 56: 127-131. 